\title{
Pengasuhan Among Untuk Menurunkan Kecenderungan Orangtua Melakukan Penderaan Pada Anak
}

\author{
Nilla Sari Dewi Iustitiani ${ }^{1}$
}

Pusat Kajian Pembangunan Masyarakat, Universitas Katolik Atma Jaya Jakarta

\author{
Ilham Nur Alfian ${ }^{2}$ \\ Departemen Psikologi Kepribadian dan Sosial Fakultas Psikologi Universitas Airlangga
}

\begin{abstract}
Cases of child abuse and neglect is dramatically increasing. Perpetrators of child abuse and neglect is the closest person to the child. A strategy that can be used to reduce the child abuse and neglect by parents is to provide parenting skills. This study aimed to look at the effectiveness of parenting skills with among training to reduce the child abuse and neglect. This research was a quantitative research using quasi-experimental methods, conducted in 11 parents in Putat Jaya, Sawahan, Surabaya. The chosen data analysis technique was the paired t-test, which the researcher first gave the pretest questionnaire about abuse behavior of parents and parenting skill and then tested again after the training was completed. The results of this study indicated that parenting skills or among training was effective to reduce the negative attitudes and behavior of parents Meanwhile, it had no significant impact on parenting knowledge.
\end{abstract}

Keywords: among, child abuse, parenting skills

\begin{abstract}
Abstrak.
Kasus penderaan pada anak semakin marak terjadi, bahkan pelaku penderaan pada anak seringkali merupakan orang terdekat dengan anak. Salah satu strategi yang dapat digunakan untuk mengurangi penderaan pada anak yang dilakukan oleh orangtua adalah dengan memberikan pelatihan pengasuhan pada orangtua. Penelitian ini bertujuan untuk melihat efektivitas pelatihan pengasuhan among untuk mengurangi kecenderungan orangtua melakukan penderaan pada anak. Penelitian ini merupakan penelitian kuantitatif dengan menggunakan metode quasi experimental yang dilakukan pada 11 orangtua di Kelurahan Putat Jaya, Kecamatan Sawahan, Surabaya. Teknik analisis data yang digunakan adalah paired t-test, dimana peneliti terlebih dahulu memberikan pretest yang mengukur perilaku penderaan orang tua dan pengasuhan among kemudian alat ukur yang sama diujikan kembali setelah pelatihan selesai. Hasil penelitian ini menunjukkan bahwa pelatihan pengasuhan among efektif digunakan untuk menurunkan kecenderungan orangtua melakukan penderaan jika ditinjau dari aspek sikap dan perilaku orangtua. Sedangkan jika ditinjau dariaspek pengetahuan, maka pelatihan pengasuhan among tidak efektif digunakan.
\end{abstract}

Kata kunci: among, penderaan anak, pengasuhan.

Korespondensi: Universitas Katolik Atma Jaya Jakarta, Jl. Jenderal Sudirman 51, Jakarta 12930, Departemen Psikologi Kepribadian dan Sosial Fakultas Psikologi Universitas Airlangga, Jl. Dharmawangsa Dalam Selatan Surabaya 60286 e-mail: ${ }^{1}$ nillasari.dewi@yahoo.com, ${ }^{2}$ ilham.nuralfian@psikologi.unair.ac.id 


\section{PENDAHULUAN}

Beberapa tahun belakangan ini, kasus kekerasan atau penderaan pada anak semakin marak. Pada beberapa pemberitaan di media disebutkan bahwa anak sering kali menjadi korban penderaan yang dilakukan oleh orangtua, bahkan tidak jarang hingga berujung pada kematian. Berdasarkan laporan Indonesia untuk Komite Anak Dunia pada tahun 2006, disebutkan bahwa 41\% kasus yang terjadi pada anak terkait dengan pencabulan dan kekerasan seksual, 41\% kasus pemerkosaan, 3\% kasus perdagangan anak, $3 \%$ kasus pembunuhan, $7 \%$ tindak penganiayaan, dan $5 \%$ lainnya tidak diketahui (Kementerian Pemberdayaan Perempuan dan Perlindungan Anak, 2014). Hal tersebut senada dengan data yang dimiliki oleh Bagian Pengaduan Masyarakat, Biro Hukum dan Humas Kementerian PP dan PA pada tahun 2013 menyatakan bahwa ada sebanyak 281 kasus penderaan, dimana 42 kasus adalah kasus penderaan terjadi pada anak ("KPP-PA optimalkan", 2014).

Di Jawa Timur, tingkat penderaan pada anak banyak terjadi di Kota Surabaya dan Malang. Berdasarkan data Pusat Krisis Berbasis Masyarakat (PKBM) Cahaya Mentari untuk wilayah Surabaya, kasus atau masalah seputar anak sangat tinggi terjadi di Kelurahan Putat Jaya, Kecamatan Sawahan. Dinyatakan pula bahwa pada wilayah tersebut terdapat 81 kasus anak yang mengalami penderaan domestik, 45 kasus penderaan seksual, 8 kasus penderaan secara ekonomi, 18 kasus anak yang terlibat dengan hukum, 14 kasus anak yang mengalami penelantaran, 134 kasus KDRT, serta 5 kasus trafficking ("DollyTutup", 2014).

Berdasarkan data penelitian tahun 2006 yang dilakukan oleh PKPM UNIKA Atma Jaya bekerja sama dengan UNICEF di beberapa kota di Indonesia, terdapat tujuh jenis penderaan yang paling banyak dialami oleh anak (Irwanto, 2006). Ketujuh jenis penderaan yang sering dialami anak tersebut tergolong dalam penderaan secara fisik dan verbal, yaitu dicubit, dimarahi, diejek, dipukul, disuruh lari, didorong, dan dibentak. Hal ini juga diperkuat oleh data yang didapatkan dari YKAI (Yayasan Kesejahteraan Anak Indonesia) bahwa pada beberapa kota di Indonesia terdapat sekitar 3.969 kasus penderaan pada anak yang terjadi dari tahun 1992 sampai dengan tahun 2002. Dimana $65.8 \%$ diantaranya merupakan penderaan secara seksual, $19.6 \%$ adalah penderaan fisik, $6.3 \%$ adalah penderaan emosional, dan 8.3 adalah penelentaran anak (Solihin, 2004).

Ironisnya, jika dilihat dari sisi pelaku, penderaan pada anak paling banyak dijumpai justru di rumah atau dimana anak tinggal dan menghabiskan waktunya. Bahkan berdasarkan data yang ada, justru pelaku penderaan pada anak adalah orangtua anak itu sendiri. Menurut hasil penelitian yang dilakukan oleh PKPM UNIKA Atma Jaya, diketahui bahwa sekitar 61.4\% penderaan pada anak paling banyak dilakukan oleh orangtua (Irwanto, 2006).

Penderaan pada anak erat kaitannya dengan faktor kultural dan struktural dalam masyarakat. Faktor kultural misalnya adalah adanya pandangan bahwa anak harus patuh kepada orangtua, sehingga secara tidak sadar hal tersebut menjadi alat pembenaran orangtua melakukan penderaan pada anak. Bila anak tidak patuh kepada orangtua, maka anak akan mendapatkan sanksi yang dapat berubah menjadi penderaan. Sedangkan faktor struktural disebabkan karena adanya hubungan yang tidak seimbang baik dalam lingkungan keluarga maupun masyarakat. Anak akan berada dalam posisi yang lemah dan rendah secara fisik, sehingga mereka akan cenderung bergantung pada orangyang lebih dewasa.

Di Indonesia sendiri, terkait dengan budaya yang ada, penderaan pada anak yang dilakukan oleh orangtua seringkali justru memperoleh pembenaran sosial, artinya pelaku tidak menerima sanksi hukum. Pada beberapa kasus, pelaku justru akan merasa bersalah jika 
tidak melakukan hal tersebut. Hal tersebut disebabkan karena adanya harapan sosial untuk mendisiplinkan anak. Hal ini diperkuat dari hasil wawancara awal yang dilakukan oleh peneliti pada tanggal 12 Mei 2015 kepada dua orang ibu muda (Ani, 27 tahun dan Sarah, 28 tahun), diketahui bahwa masih ada orangtua yang beranggapan bahwa memukul anak adalah sarana yang tepat agar anak menjadi jera dan menurut kepada orangtua. Mereka juga merasa pemukulan terhadap anak merupakan tindakan yang wajar apabila dilakukan dengan batasan tertentu, yaitu tidak menggunakan benda atau memukul dengan tangan kosong, dan pemukulan atau mencubit dilakukan di tempat yang tidak terlihat oleh orang lain. Selain itu mitos "diujung rotan ada emas" juga masih dimiliki oleh beberapa orangtua (PKPM, 2003, 2006 dalam Irwanto, 2006).

Kurangnya kesadaran dari orangtua inilah yang kemudian membuat anak menjadi rentan mengalami penderaan. Anak yang mendapatkan perlakuan buruk dari orangtua sering kali dianggap sebagai anak nakal dan tidak menurut. Bahkan ada beberapa anak yang justru dianggap sebagai beban dan kelahirannya memang tidak diinginkan. Berdasarkan pemaparan di atas maka dapat dikatakan bahwa anak-anak di Indonesia belum sepenuhnya mendapatkan perlindungan terhadap segala bentuk penderaan, baik yang berupa kekerasan, penelantaran, hingga diskriminasi.

Keluarga seharusnya berfungsi menjadi lembaga sosial pertama dan utama yang memiliki peranan penting dalam memberikan perlindungan pada anak. Peran keluarga seharusnya memberikan kasih sayang, rasa aman, kedamaian dan kehangatan pada anak sebagai anggota keluarga menjadi semakin bergeser. Berdasarkan hasil penelitian yang dilakukan oleh PUSKAPA-UI dengan UNICEF (Sambo, 2014), dinyatakan bahwa salah satu strategi kunci untuk mengatasi penderaan pada anak adalah dengan melakukan intervensi kepada orangtua yang berkaitan dengan keterampilan orang tua dalam mengasuh anak. Hal ini didasari pada beberapa kasus, dimana anak mengalami penderaan karena disebabkan adanya masalah dalam pengasuhan anak (parenting disorder). Hal tersebut diperkuat dengan hasil penelitian dari MacMillan, dkk (2009), dimana dikatakan bahwa salah satu program yang cukup efektif dalam mengatasi penderaan pada anak adalah dengan program pengasuhan positif atau The Triple $P$ (Positive Parenting Program). Pada program ini, orangtua diberikan pembekalan mengenai kemampuan pengasuhan yang baik dan positif untuk mengoptimalkan tumbuh dan kembang anak. Terkait dengan hal tersebut, maka dapat disimpulkan bahwa strategi yang tepat dalam mengatasi penderaan pada anak adalah dalam lingkup terkecil atau primer, dimana perlu adanya pendidikan atau pelatihan yang bertujuan untuk memberikan pengetahuan kepada orangtua mengenai pengasuhan anak yang positif.

Tentunya dalam menerapkan kemampuan dalam pengasuhan yang baik, perlu juga memperhatikan budaya dan kearifan lokal. Idealnya, orangtua dalam mendidik anak akan mengambil bagian dalam perkembangan anak menuju kepada kedewasaan sehingga anak akan belajar untuk mandiri baik melalui proses belajar sosial dan modeling (Belsky, 1994 dalam Andayani dan Koentjoro, 2004). Berndt (1997) membagi pengasuhan menjadi tiga hal, yaitu kehangatan (warmth), kontrol (control), dan keterlibatan (involvement). Jika dikaitkan dengan kearifan dan budaya lokal, ketiga prinsip tersebut hampir sama dengan konsep among yang diungkapkan oleh Ki Hajar Dewantara berdasarkan budaya Jawa.

Among berasal dari bahasa Jawa yaitu momong atau mong yang artinya mengasuh anak. Among sendiri berdasarkan pada tiga prinsip dasar, yaitu asah, asih, dan asuh yang berarti mendidik dan mengajarkan anak sepanjang waktu dengan penuh kasih sayang (Wangid, 2009). Pengasuhan dengan 
pendekatan among ini mengajarkan kepada orangtua untuk mengasuh dan memelihara anak dengan penuh suka cita dengan memberi kebebasan kepada anak bergerak menurut kemauannya dan berkembang menurut bakat kemampuannya (Tauhid dalam Sholeh, 2010). Ketiga prinsip yang ada dalam konsep among mewajibkan pamong atau pengasuh untuk mengingat dan meningkatkan bakat dan kemampuan anak tanpa disertai dengan perintah, paksaan, dan hukuman. Sebaliknya, pamong atau pengasuh harus dapat memberi bimbingan, menyokong anak dalam tumbuh kembang, melindungi anak dari hal-hal yang dapat menghambat proses tumbuh kembangnya dan juga mendekatkan anak dengan alam dan lingkungan atau masyarakat sekitarnya. Pengasuhan among juga mengajarkan orangtua untuk mendidik anak sesuai dengan karakter anak tanpa menggunakan hukuman-hukuman yang bersifat kekerasan atau penderaan.

Pengasuhan (parenting) sendiri adalah proses mendorong dan mendukung perkembangan anak baik secara fisik, emosi, sosial, maupun perkembangan intelektual anak dari kecil hingga dewasa (Hildebrand, 200o). Berdasarkan pemaparan sebelumnya, maka peneliti menarik kesimpulan bahwa konsep among dirasa cukup tepat karena sesuai dengan prinsip pengasuhan itu sendiri, dimana orangtua mendorong dan mendukung tumbuh kembang anak sesuai dengan karakter anak. Pelatihan kemampuan pengasuhan dengan menggunakan sistem among ini akan terdiri dari beberapa sesi, yaitu memberikan pengetahuan dan pemahaman kepada orangtua mengenai anak dan tahap perkembangannya; hak, kebutuhan, dan tanggung jawab anak; serta ketiga prinsip dari among, yaitu asih, asah, dan asuh. Berdasarkan beberapa penelitian dikatakan bahwa salah satu faktor pemicu terjadinya penderaan pada anak adalah kurangnya pemahaman orangtua mengenai karakter dan tahap perkembangan anak. Selain memberikan materi berupa prinsip-prinsip among, peneliti juga memberikan materi berupa tahap perkembangan anak dan hak-hak anak.

Berdasarkan latar belakang tersebut, maka peneliti tertarik untuk melihat dampak dari pemberian pelatihan pengasuhan yang berbasis pada budaya lokal kepada orangtua sebagai salah satu upaya untuk mengurangi kecenderungan orangtua melakukan penderaan pada anak. Pada penelitian kali ini, peneliti menggunakan metode pelatihan yang bersifat experimental learning, dimana orangtua selama proses pelatihan akan belajar melalui pengalaman-pengalaman, baik pengalaman pribadi di masa lalu maupun pengalaman yang diperoleh selama pelatihan. Pelatihan ini tidak hanya bertujuan pada perubahan secara kognitif saja, tetapi juga pada afektif dan konatif. Pelatihan ini dirasa penting sebagai alternatif pendidikan kepada orangtua yang bertujuan untuk meningkatkan keterampilan orangtua dalam mengasuh anak sehingga diharapkan dapat mengurangi kecenderungan orangtua untuk melakukan penderaan pada anak.

Oleh karena itu, berdasarkan pemaparan di atas, maka peneliti merasa perlu untuk melihat lebih jauh lagi mengenai efektivitas pelatihan pengasuhan berbasis budaya lokal among sebagai upaya untuk mengurangi kecenderungan orang tua melakukan penderaan pada anak.

\section{METODE}

\section{Tipe penelitian}

Penelitian ini merupakan penelitian kuantitatif dengan menggunakan metode quasi experimental yaitu suatu rancangan yang digunakan untuk melihat pengaruh dari suatu pemberian perlakuan terhadap permasalahan. Pada quasi experimental, partisipan tidak dipilih secara random ke dalam suatu grup. Quasi experimental dikondisikan seperti true experiment, dimana pada beberapa situasi tidak 
mungkin dilakukan eksperimen. Penelitian ini menggunakan satu kelompok eksperimental sehingga setiap partisipan dalam kelompok akan menjadi pembanding bagi dirinya sendiri, yaitu dengan membandingkan skor sebelum (pre-test) dan skor sesudah diberikan perlakuan (post-test) (Robinson, 1981).

\section{Partisipan penelitian}

Populasi penelitian ini adalah orangtua yang tinggal di Kelurahan Putat Jaya, Kecamatan Sawahan, Surabaya. Sedangkan sampel yang akan digunakan dalam penelitian ini adalah orangtua yang memiliki kecenderungan melakukan penderaan kepada anak mereka. Pemilihan sampel menggunakan teknik non-randomized sampling. Dimana peneliti akan memberikan alat ukur kepada orangtua yang bertujuan untuk melakukan screening pada orangtua yang memiliki kecenderungan melakukan penderaan pada anak dan yang tidak memiliki kecenderungan melakukan penderaan. Orangtua yang memiliki kecenderungan melakukan penderaan inilah yang akan dipilih menjadi sampel dari penelitian ini.

Orangtua yang menjadi sampel pada penelitian ini adalah ibu-ibu, hal ini disebabkan karena asumsi peneliti bahwa ibu akan lebih cenderung dominan dalam pengasuhan. Selain itu ibu, terutama yang tidak bekerja akan lebih banyak memiliki waktu bersama dengan anak.

Penjaringan sampel penelitian dilakukan melalui dua cara, yaitu dengan menggunakan teknik accidental sampling, dimana peneliti mencari responden yang memiliki kriteria sesuai dengan kriteria yang telah ditetapkan oleh peneliti. Berdasarkan teknik ini, peneliti mendapatkan 48 orang responden yang bersedia untuk mengisi lembar check list mengenai penderaan pada anak. Peneliti kemudian mengolah data yang ada dan didapati terdapat 30 orang responden yang melakukan penderaan pada anak. Peneliti kemudian menghubungi ke-3o orang tersebut untuk meminta kesediaannya mengikuti pelatihan.
Dari 30 orang tersebut, terdapat 15 orang yang memberikan respon dimana 7 diantaranya menyatakan bersedia mengikuti pelatihan. Tetapi pada saat waktu pelaksanaan pelatihan, ternyata hanya 3 orang saja yang hadir mengikuti pelatihan selama dua hari.

Karena jumlah responden pada penelitian pertama yang terlalu sedikit, maka peneliti kemudian melakukan pelatihan kedua. Peneliti menggunakan teknik snowballing, yaitu dengan cara meminta bantuan dari salah satu responden yang menyatakan bersedia mengikuti pelatihan untuk mengumpulkan ibu-ibu yang memiliki anak berusia 6-12 tahun, bersuku Jawa, dan tinggal di Kelurahan Putat Jaya, Kecamatan Sawahan, Surabaya untuk mengikuti pelatihan yang diadakan oleh peneliti. Berdasarkan teknik tersebut, maka terkumpul 8 orang responden yang sesuai dengan kriteria sampel penelitian ini dan menyatakan bersedia mengikuti pelatihan.

\section{Pengumpulan data}

Penelitian ini akan menggunakan dua alat ukur, yaitu screening check list kecenderungan melakukan penderaan pada anak dan juga kuesioner pengasuhan among. Screening check list berisi pernyataan mengenai bentuk-bentuk perilaku pengasuhan baik berupa pengasuhan yang positif maupun penderaan yang pernah dilakukan oleh orang tua kepada anak. Alat ukur ini akan diberikan dua kali, yaitu pertama untuk memilih responden penelitian dan yang kedua adalah untuk melihat adanya penurunan angka kecenderungan melakukan penderaan pada anak setelah orang tua diberikan pelatihan pengasuhanberbasis budaya lokal. Sedangkan kuesioner pengasuhan among digunakan untuk mengukur pengetahuan serta sikap dari responden mengenai pengasuhan.

Selain itu, dalam penelitian ini juga menggunakan alat eksperimen yang berupa modul pelatihan yang berisi tentang keterampilan pengasuhan yang telah dimodifikasi oleh peneliti dengan menggunakan prinsip among. Modifikasi yang 
dilakukan akan disesuaikan dengan tema-tema yang ada dan disajikan sedemikian rupa dengan tujuan agar para orang tua dapat memahami dan juga mempraktekkan materi yang diberikan. Ada tiga prinsip yang akan dilatihkan dalam pelatihan ini, yaitu asah, asih, dan asuh. Pelatihan yang diberikan bertujuan bukan hanya mengubah wawasan, pengetahuan para orang tua saja mengenai penderaan pada anak tetapi juga diharapkan dapat mengubah perilaku orang tua sehingga tidak melakukan penderaan pada anak.

\section{Teknik analisis data}

Teknik analisis yang akan digunakan dalam penelitian ini adalah dengan mengunakan uji $\mathrm{T}$, yaitu paired sample t-test. Dimana uji ini digunakan untuk membandingkan rerata dari suatu sampel yang berpasangan (paired).

\section{HASIL PENELITIAN}

Berdasarkan hasil screening checklist, diketahui bahwa dari 47 responden terdapat 16 orang $(34.0 \%)$ yang tidak pernah mengajarkan anak mengenai bahayanya melakukan hubungan seksual sebelum menikah, 2 orang reponden $(4.3 \%)$ yang tidak pernah memangku anaknya, 1 orang responden (2.1\%) yang tidak pernah memeluk anaknya, 1 orang responden (2.1\%) yang tidak pernah mengatakan hal-hal baik tentang anaknya, 1 orang responden (2.1\%) yang tidak pernah memperhatikan anaknya, dan 1 orang responden (2.1\%) yang tidak pernah mengingatkan anak untuk menjaga kesehatan alat kelaminnya.

Sedangkan untuk perilaku penderaannya sendiri, dari hasil screening check list diketahui bahwa perilaku memarahi anak adalah perilaku yang paling sering dilakukan oleh orang tua $(\mathrm{N}=40,85.1 \%)$. Kemudian sebanyak 32 orang (68.1\%) membentak anak, 31 orang $(66.0 \%)$ mencubit anak, dan 20 orang (42.6\%) memukul anak. Sedangkan perilaku penderaan yang tidak pernah dilakukan adalah memaksa anak melakukan hubungan badan (100\%).

Berdasarkan hasil dari screening check list, diketahui terdapat beberapa responden yang melakukan penderaan pada anak. Tetapi hanya 11 orang yang menyatakan bersedia mengikuti penelitian lebih lanjut dengan terlibat dalam pelatihan pengasuhan among.

ANALISIS DATA

Tabel 1.

Perbandingan Frekuensi Perilaku Penderaan yang Dilakukan Partisipan Pretest-Post Test (N=11)

\begin{tabular}{lccc}
\hline Target Perilaku & Frekuensi Postest & Frekuensi Pretest & Keterangan \\
\hline Memukul & 6 & 4 & Turun \\
Menendang & 0 & 0 & Tetap \\
Menampar & 1 & 0 & Turun \\
Mencubit & 10 & 10 & Tetap \\
Melempar dengan benda & 2 & 0 & Turun \\
Memarahi & 11 & 10 & Turun \\
Membentak & 8 & 6 & Turun \\
Mengata-ngatai & 2 & 1 & Turun \\
Mencaci-maki & 2 & 0 & Turun \\
Melarang anak melakukan hal yang disukainya & 4 & 2 & Turun \\
Memaksa anak melakukan hal tertentu & 3 & 1 & Turun \\
Merampas barang kesukaan & 1 & 0 & Turun \\
Memaksa anak melakukan hubungan badan & 0 & 0 & Tetap \\
Tidak peduli terhadap kebutuhan anak & 0 & 0 & Tetap \\
Cuek terhadap anak & 0 & 0 & Tetap \\
Tidak memiliki waktu bersama anak & 0 & 0 & Tetap \\
\hline
\end{tabular}

